\title{
鉄塔-送電線系の地震応答解析のための簡易計算図表
}

\section{SIMPLIFIED NOMOGRAMS FOR ANALYZING EARTHQUAKE RESPONSES OF TOWERS AND TRANSMISSION LINES SYSTEMS}

\author{
小坪清真*·高西照彦**・井嶋克 志*** \\ By Seima KOTSUBO, Teruhiko TAKANISHI and Katsushi IJIMA
}

\begin{abstract}
Though a transmission line has tremendously numerous modes, responses of transmission lines subjected to earthquakes can be computed by the method of modal analysis adopting only a few symmetric modes of transversal wave in low frequencies and modes longitudinal one in high frequencies. This paper presents simplified nomograms for computing natural frequencies, additional tensions and participation factors of their modes of diverse transmission lines for analyzing earthquake responses of towers and transmission lines systems.
\end{abstract}

Keywords : tower, cable, earthquake resistant design

\section{1. まえがき}

著者らは，超高送電鉄塔の耐震安全性検討のために， 鉄塔と送電線の動的相互作用を考慮した，厳密で実用的 な鉄塔-送電線系の線路方向の地震応答解析法として 2 つの方法を提案した.

1 つの方法は，送電線をばねとみなして鉄塔一送電線 系の自由振動特性を求め, 得られた全体系の振動特性を 用いてモーダルアナリシスにより地震応答解析を行うも のである2). また, もう 1 つの解析法は, 鉄塔のみの自 由振動特性および送電線のみの自由振動特性を用いて, 両者の連成振動としてそれぞれにモーダルアナリシスを 利用して鉄塔-送電線系の地震応答解析を行う方法であ $る^{3)}$.

これらの $2 つ の$ 解析法の合理的な点として次のことが 挙げられる. 両支持点に地震波を受ける送電線の張力応 答には, 地震波の振動数域で多数存在するモードのなか で低振動数域の横波の対称モ一ドと高振動数域の縦波の

* 正会員 工博 九州大学教授 工学部土木工学科 （テ812 福岡市東区箱崎 6-10-1）

** 正会員 工博 九州工業大学助教授 開発土木工学科. ( \%804 北九州市戸畑区仙水町 1-1)

*** 正会員 工博 佐賀大学講師 理工学部建設工学科 （ T840 佐賀市本庄町 1)
モードのみが寄与し, その他のモードはほとんど寄与し ないのであるが, あらかじめ寄与するモードのみを取捨 選択できることである. すなわち，第 1 の方法において は, すべての送電線のモードを使ったとすれば, 送電線 のばね定数の振動数特性は非常に複雑になるが, あらか じめ送電線のモードの取捨選択を行い, 低振動数域の横 波の対称モードと高振動数域の縦波のモードのみを採用 して計算することにより, 送電線のばね定数の振動数特 性の簡易化を図ることができる. また, 第 2 の解析法で は，鉄塔と送電線それぞれにモーダルアナリシスを適用 するとき, 特に送電線の振動に対して, 張力応答に大き な影響を及ぼす低振動数域の横波の対称モードと高振動 数域の縦波のモードのみを採用することにより, 自由度 数の大幅な低減を図ることができる.

しかし，実在の鉄塔と送電線が連続する系を考えた場 合, 送電線の支間およびサグは種々異なり, 鉄塔-送電 線系の地震応答解析に採用される送電線のモードも種々 異なってくるので, モ一ドの計算およびその取捨選択に も膨大な手間を必要とする. したがって, 送電線の多数 のモードのなかから, 鉄塔-送電線系の地震応答解析に 必要なモードのみを合理的に計算選択し, それらのモ一 ドの固有円振動数, 水平付加張力, 刺激係数を容易に得 ることができなければ上記の解析法は実用的とはいえな 
い。これらのモードを解析的に求めるには非常に多くの 計算を要するので, 本ノートは, 鉄塔-送電線系の地震 応答解析を容易に行うために, 送電線のモードの選択法 およびそれらのモードの無次元固有円振動数, 無次元水 平付加張力, 刺激係数を求めるための計算図表を示した ものである.

\section{2. 送電線の無次元固有円振動数, 無次元水平 付加張力モードおよび刺激係数}

送電線の面内自由振動解析は, 図一1 に示される座標 系のもとに行った．送電線は連続体のまま取り扱い，完 全可撓性, 伸張性を有する一様な水平ケーブルとして, $2 つ$ 無次元パラメーターのいろいろな值について送電 線の面内自由振動解析を行い, 送電線の無次元固有円振 動数, 無次元水平付加張力モード, 送電線一端の面内水 平変位に対する刺激係数を求めた. $2 つ の$ 無次元パラ メーターの 1 つは, $\rho g L /(8 H)(\rho g$ : 送電線の単位長 さ当たり重量, $L$ : 送電線の支間長, $H$ : 初期水平張力 $)$ であり，その值はサグ比 $(D / L, D:$ 送電線のサグ $)$ が 0.1 以下のように小さい場合, $\rho g L /(8 H) \doteqdot D / L$ とな り，その誤差は $0.3 \%$ 以下である. また，もう 1 つの パラメーターは $\nu=\sqrt{E A / H}$ ( $E A$ : 送電線の伸び剛性 $)$ であり, 送電線中の縦波の伝播速度 $(\sqrt{E A / \rho})$ と横波 の伝播速度 $(\sqrt{H / \rho})$ の比を表わしている。なお，詳 細な解法は論文 1）に述べているので，ここでは省略す る.

以下の解析においては, 次式の基準化を行っている.

$$
\int_{0}^{\sigma}\left\{\left(\bar{u}_{j}\right)^{2}+\left(\bar{v}_{j}\right)^{2}\right\} d s=1
$$

ここに, $\bar{u}_{j}=\bar{U}_{j} / L, \bar{v}_{j}=\bar{V}_{j} / L:$ 送電線の $j$ 次の無次 元水平, 鉛直変位モード, $s=S / L$ : 送電線に沿う無次 元距離, $S$ : 送電線に沿う距離, $\sigma=S_{0} / L:$ 送電線の無 次元長, $S_{0}$ : 送電線長である.

\section{（1） 低振動数域の横波の対称モード}

低振動数域の横波の対称モードの 2 次および 3 次の無 次元固有円振動数 $\left(\omega_{j}=\Omega_{j} / \Omega_{0}, \Omega_{0}\right.$ : 長さ $L$, 初期張力 $H$ の弦の基準円振動数), 送電線左端の無次元水平付加 張力 $\left(\bar{h}_{j}(0)=\bar{H}_{j}(0) / H\right)$, および送電線右端の右向き無 次元単位水平変位 $(\bar{\delta}=\bar{\Delta} / L)$ に対する刺激係数を, そ れぞれ図一2，3，4 に示す。一般に，送電線のサグ比 $(D / L \doteqdot \rho g L /(8 H))$ は $0.03 \sim 0.09$ の間に, 送電線の 縦波と横波の伝播速度比 $(\nu=\sqrt{E A / H})$ は $20 \sim 45$ の 間に存在する。

図一2 4 を対称モードの 1 次〜 5 次まで準備し,まず, 図加ら $\rho g L /(8 H)$ と $\nu$ の值に従って $\omega_{j}, \bar{h}_{j}(0), \beta_{j}^{r}$ を読み取り，それらのモードのなかで $\beta_{j}^{r} \bar{h}_{j}(0)$ の大 きい值のモードのみを送電線の応答計算に採用すればよ
い.なお，送電線の対称モードにおいて，送電線両端の 付加張力は等しく $\left(\bar{h}_{j}(\sigma)=\bar{h}_{j}(0)\right)$, 送電線左端の右 向き無次元単位水平変位に対する刺激係数は $\beta_{j}^{l}=-\beta_{j}^{r}$ となる．対称モードの 1 次および 4,5 次は省略した。

（2）縦波のモード

縦波の 1 次モードの無次元固有円振動数, 無次元水平 付加張力モード值および刺激係数をそれぞれ図一5の ( a )，（b ），（c）に示す. 図中のサフィックス $b$ は 縦波の 1 次モードを, サフィックス $b^{\prime}$ は縦波の 1 次モ一 ドに近接する横波の逆対称モードを表わす．図からわか

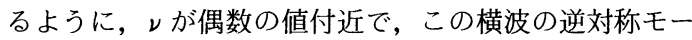
ドの無次元水平付加張力と刺激係数は大きくなり，図中 の $\times$ 印で縦波の 1 次モードのそれらの值と一致する。し たがって, 送電線の地震応答計算には, 縦波の 1 次モ一 ドとともに，そのモードに近接する横波の逆対称モード も必要となる. しかし, 図のように $\bar{h}_{j}(0)$ および $\beta_{j}^{r}$ の值が大きく変動すれば, 図からの読 み取り誤差が生じるとともに，実在送電線の $\nu$ の値の 誤差により $\bar{h}_{j}(0)$ および $\beta_{j}^{r}$ の值も大きく変わり, こ れらの図は実用的ではない。したがって，種々の送電線 の応答計算を行った結果, 縦波の 1 次モードと横波の逆 対称モードを 1 つのモードとして，その無次元固有円振 動数は $\rho g L /(8 H)$ の值にかかわらず, $\omega_{j}=\nu, \bar{h}_{j}(0)$ および $\beta_{j}^{r}$ は図一 5 （b ），（c）に示される点線から值を 求めても差し支えないことがわかった。なお（4）で 示すとおり送電線の張力応答計算に点線で示される值を 用いても，その誤差は $1 \%$ 以下であった.

この補正された $\bar{h}_{j}(0)$ および $\beta_{j}^{r}$ の値をまとめて図 一に示す. 縦波の 1 次モ一ドの水平付加張力は送電線 両端で逆対称 $\left(\bar{h}_{j}(\sigma)=-\bar{h}_{j}(0)\right)$, 送電線左端の右向き の無次元単位水平変位に対する刺激係数は右端の右向き 変位に対するそれと等しい $\left(\beta_{j}^{l}=\beta_{j}^{r}\right)$. 図には縦波の 2 次モードも示しており, その無次元固有円振動数は $\rho g L /(8 H)$ の值にかかわらず $\omega_{j}=2 \nu$, 無次元水平付 加張力は送電線両端で等しく $\left(\bar{h}_{j}(\sigma)=\bar{h}_{j}(0)\right)$, その値 は縦波の 1 次モードの 2 倍の值, 刺激係数は $\beta_{j}^{l}=-\beta_{j}^{r}$ となる。

最後に, 送電線一端の静的な外向き無次元単位水平変 位による無次元水平付加張力 $\left(h_{0}=H_{0} / H\right)$ を図一7に 示す.

\section{（3）次 元 化}

以上の図から得られた送電線の無次元固有円振動数, 無次元水平付加張力, 刺激係数の值の次元化は, 刺激係 数についてはそのまま $\beta_{j}^{r}, \beta_{j}^{l}$ の值を用い, 他の値は次 式で計算すればよい。

$$
\begin{aligned}
& \Omega_{j}=\Omega_{0} \omega_{j}=(\pi / L) \sqrt{H / \rho \omega_{j}} \\
& \bar{H}_{j}(0)=(H / L) \bar{h}_{j}(0)
\end{aligned}
$$




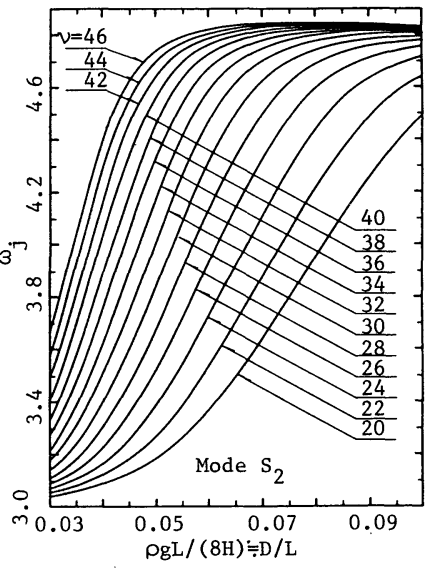

(a) Mode $\mathrm{S}_{2}$

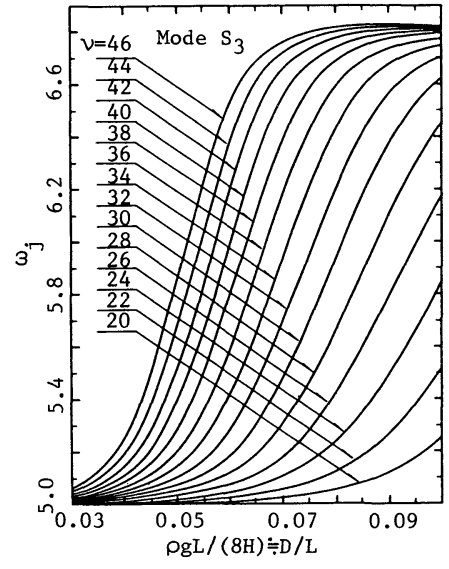

(b) Mode $\mathrm{S}_{3}$

Fig. $2 \omega_{j}$ of symmetric models in low frequencies.

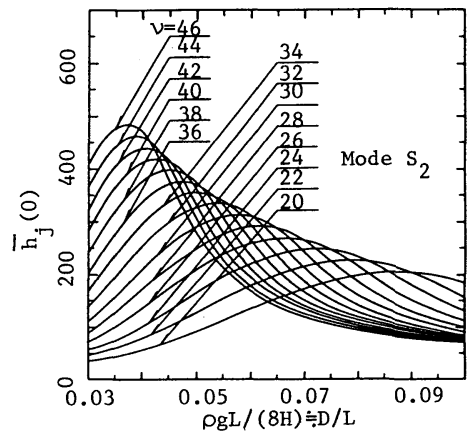

(a) Mode $\mathrm{S}_{2}$

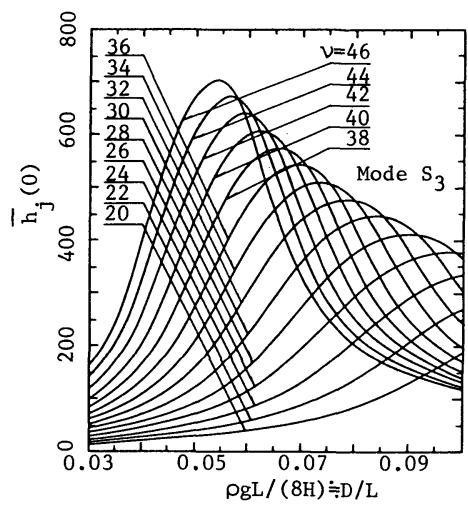

(b) Mode $\mathrm{S}_{3}$

Fig. $3 \bar{h}_{j}(0)$ of symmetric modes in low frequencies $\left(\bar{h}_{j}(\sigma)=\bar{h}_{j}(0)\right)$.

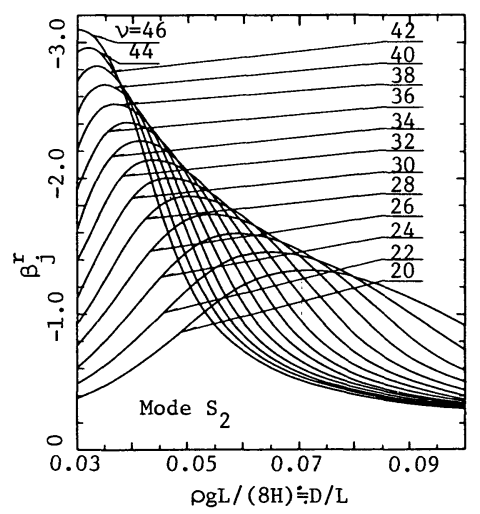

(a) Mode $\mathrm{S}_{2}$

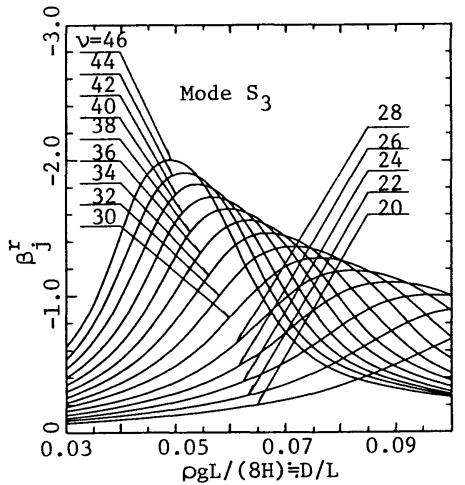

(b) Mode $\mathrm{S}_{3}$

Fig. $4 \beta_{j}^{r}$ of symmetric modes in low frequencies $\left(\beta_{j}^{l}=-\beta_{j}^{r}\right)$.

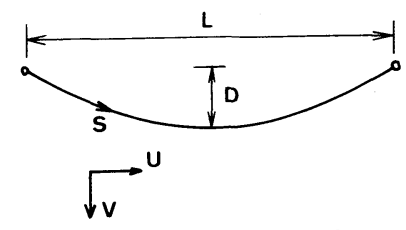

$\rho$ : Mass per unit length

EA:Extensional rigidity

H :Horizontal component of static tension

Fig. 1 Transmission line.

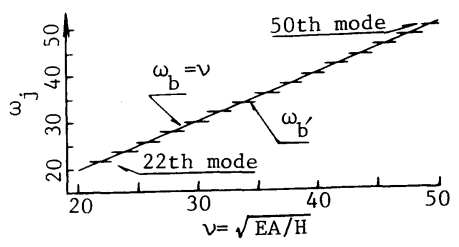

(a) $\omega_{j}$

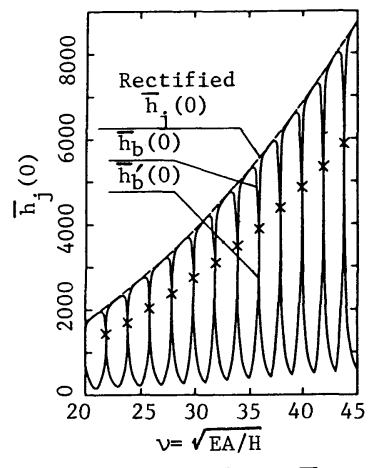

(b) $\bar{h}_{j}(0) \quad\left(\bar{h}_{j}(\sigma)=-\bar{h}_{j}(0)\right)$

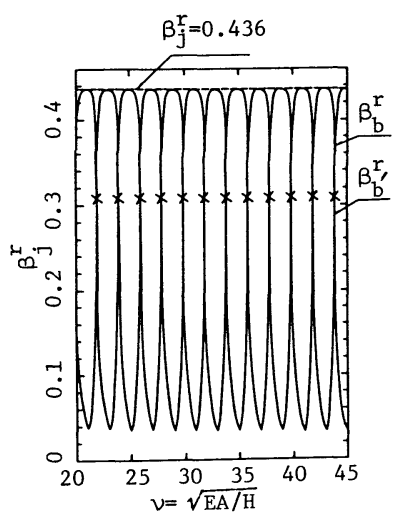

(c) $\beta_{j}^{r}\left(\beta_{j}^{1}=\beta_{j}^{r}\right)$

Fig. 5 1st mode of longitudinal wave $(\rho g L /(8 H)=0.05)$. 


$$
\begin{aligned}
& \bar{H}_{j}\left(S_{0}\right)=(H / L) \bar{h}_{j}(\sigma) \\
& H_{0}=(H / L) h_{0}
\end{aligned}
$$

\section{（4）数值計算例}

上述の図を用いて，表一2の左に示す鉄塔-送電線系 の地震応答計算を行った．数値計算に用いた鉄塔と送電 線の諸元は文献 3）の中で用いたそれと同じであり，送 電線については, 支間長 $L=488 \mathrm{~m}$, サグ $D=28.9 \mathrm{~m}$, 単位長さ当たり質量 $\rho=10.8 \mathrm{~kg} / \mathrm{m}$, 伸び剛性 $E A=179$ $\mathrm{MN}$, 初期水平張力 $H=110 \mathrm{kN}$ である.これらの値か ら本送電線について, $\rho g L /(8 H)=0.059, \nu=$ $\sqrt{E A / H}=40.2$ の 2 つ無次元パラメーターが得られ, 図表加送電線の無次元固有円振動数, 刺激係数, 無次 元水平付加張力を求めれば，表一1の B 欄に示す值と なった．表一1の A 欄には理論值を示しているが，A 欄 の值と B欄の值はほぼ等しいことがわかる。

また，表一2には鉄塔-送電線系の San Fernando 地 震 $\left(\mathrm{N} 21 \mathrm{E}\right.$, 最大加速度 $\left.216 \mathrm{~cm} / \mathrm{s}^{2}\right)$ に対する応答を, 表一1の A 欄と B 欄それぞれの值を用いて計算した結果 を示している．鉄塔と送電線の減衰定数はともに $2 \%$ とした. 鉄塔と送電線の接続点の水平付加張力の応答最 大值および鉄塔天端の加速度の応答最大値は，図表から 得られた送電線の自由振動特性値を用いてもよい精度の 値が得られることがわかる.

\section{3. あとがき}

本ノートは, 送電線両端のば社定数の振動数特性計 算1)，および論文 2)，3）に示した鉄塔-送電線系の地震 応答計算を容易に行うために必要な送電線の低振動数域 の対称モードと高振動数域の縱波のモードの固有円振動 数, 水平付加張力, 刺激係数の計算図表を示したもので ある。

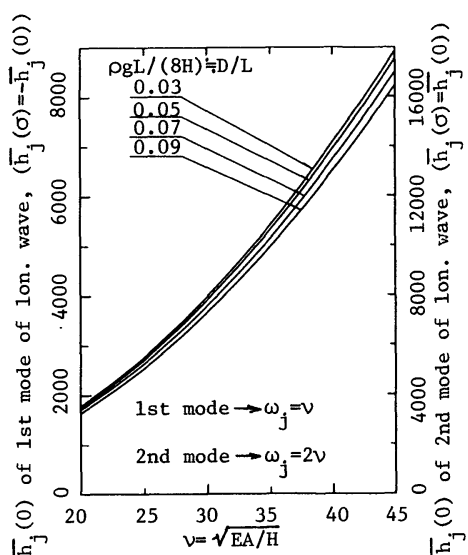

(a) $\bar{h}_{j}(0)$

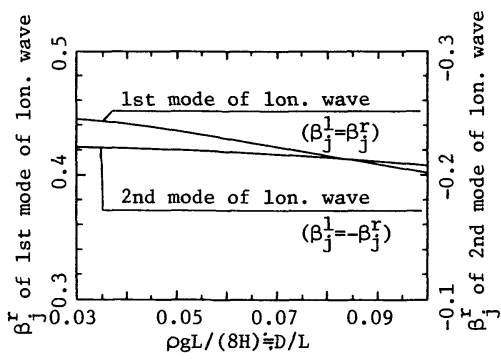

(b) $\beta_{j}^{r}(20 \leqq \nu \leqq 45)$
参 考 文 献

1）小坪清真・高西照彦・井䳋克志・園田敏矢：送電線のば ね定数の振動数特性, 土木学会論文集, No. 344/I -1, pp. $225 \sim 234,1984.4$.

2）小坪清真・高西照彦・井鴄克志・烏野 清 : 鉄塔の耐震 性に及ぼす送電線の影響, 土木学会論文集, No. 344／I -1 , pp. 271 278, 1984. 4 .

3）小坪清真・高西照彦・井嶋克志・鳥野 清 : 鉄塔-送電線 系の地震応答解析法, 土木学会論文集, No. $368 /$ I -5, 1986. 4.

(1985.8.31 • 受付)

Table 1 Dimensionless natural circular frequencies, participation factors and dimensionless additional tensions.

\begin{tabular}{|c|c|c|c|c|c|c|}
\cline { 2 - 7 } \multicolumn{1}{c|}{} & \multicolumn{2}{c|}{$\omega_{j}$} & \multicolumn{2}{c|}{$\beta_{j}$} & \multicolumn{2}{c|}{$\overline{\mathrm{h}}_{\mathbf{j}}(0)$} \\
\cline { 2 - 7 } \multicolumn{1}{c|}{} & $\mathrm{A}$ & $\mathrm{B}$ & $\mathrm{A}$ & $\mathrm{B}$ & $\mathrm{A}$ & $\mathrm{B}$ \\
\hline $\mathrm{S}_{1}$ & 2.805 & 2.80 & -0.8589 & -0.86 & 66.72 & 60 \\
\hline $\mathrm{S}_{2}$ & 4.760 & 4.76 & -0.9703 & -0.95 & 217.0 & 210 \\
\hline $\mathrm{S}_{3}$ & 5.966 & 6.00 & -1.724 & -1.70 & 605.7 & 600 \\
\hline $\mathrm{S}_{4}$ & 7.090 & 7.10 & -0.5524 & -0.56 & 274.0 & 280 \\
\hline $\mathrm{S}_{5}$ & 8.987 & 8.99 & -0.1422 & -0.14 & 113.4 & 110 \\
\hline $\mathrm{L}_{1}$ & 39.80 & \multirow{2}{*}{40.4} & 0.0614 & \multirow{2}{*}{0.43} & 959.5 & \multirow{2}{*}{7000} \\
\cline { 2 - 4 } \cline { 6 - 7 } & 40.50 & & 0.4293 & & 6949 & \\
\hline $\mathrm{L}_{2}$ & 80.33 & \multirow{2}{*}{80.8} & -0.2170 & \multirow{2}{*}{-0.22} & 13820 & \multirow{2}{*}{14000} \\
\cline { 2 - 3 } \cline { 6 - 7 } & 80.64 & & -0.0306 & & 1962 & \\
\hline
\end{tabular}

A:Theoretical values

B:Values obtained by nomograms

$\mathrm{L}_{1}, \mathrm{~L}_{2}$ :1st mode of longitudinal wave and 2 nd one

Table 2 Peak responses of tower and transmission lines for the San Fernando earthquake.

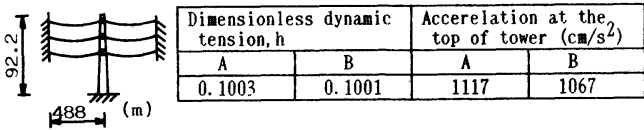

Fig. 6 Rectified $\bar{h}_{j}(0)$ and $\beta_{j}^{r}$ of lst mode of longitudinal wave and 2nd one.

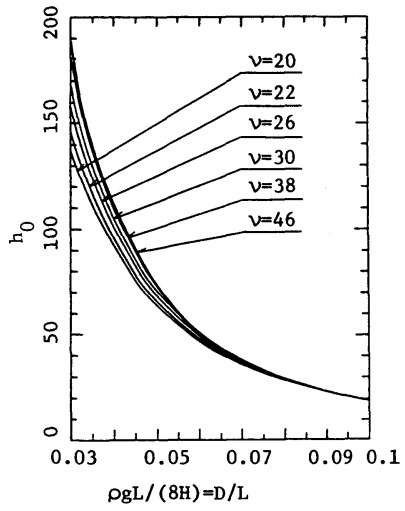

Fig.7 Dimensionless static additional tension $h_{0}$. 